\title{
Development and Validation of a RP-HPLC Method for Quantitative Analysis of Linagliptin in Bulk and Dosage Forms
}

\section{J oy Chandra Rajbangshi ${ }^{1}$, Md. Mahbubul Alam ${ }^{2}$, Md. Shahadat Hossain ${ }^{2}$, Md. Samiul Islam ${ }^{2}$ and Abu Shara Shamsur Rouf ${ }^{2}$}

\author{
${ }^{1}$ Department of Pharmacy, Dhaka International University, Dhaka-1213, Bangladesh \\ ${ }^{2}$ Department of Pharmaceutical Technology, University of Dhaka, Dhaka-1000, Bangladesh
}

(Received: May 22, 2018; Accepted: June 8, 2018; Published (web): December 10, 2018)

\begin{abstract}
This research was aimed to establish a versatile, sensitive, rapid and validated RP-HPLC method to analyze linagliptin in bulk as well as in pharmaceutical dosage forms. Liquid chromatography was performed on HPLC system and $20 \mu 1$ of samples were injected into a $C_{18}$ column $(150$ x $4.6 \mathrm{~mm}$ i.d., $5 \mu \mathrm{m}$ particle size $)$ and the eluents were monitored through a PDA detector at $239 \mathrm{~nm}$. An isocratic method with a flow rate of $1 \mathrm{ml} / \mathrm{min}$ was used to elute the compounds with a mobile phase comprised of 70:30 v/v mixture of phosphate buffer ( $\mathrm{pH} 6.8 \pm 0.2)$ and acetonitrile. The retention time of the compound was found to be 2.8 minutes. According to the ICH Q2(R1) guidelines, the method was validated by establishing several analytical parameters such as system suitability, specificity, linearity, accuracy, precision, limit of detection (LOD), limit of quantitation (LOQ), ruggedness and robustness to assay linagliptin. The method showed good linearity $\left(R^{2}=0.9981\right)$ over the concentration ranges of 40 $-60 \mu \mathrm{g} / \mathrm{ml}$ with a recovery between $99.48 \% \pm 0.38 \% \mathrm{RSD}$ to $100.22 \% \pm 0.011 \% \mathrm{RSD}$, whereas the LOD and LOQ values were $0.05 \mu \mathrm{g} / \mathrm{ml}$ and $0.15 \mu \mathrm{g} / \mathrm{ml}$, respectively. The relative standard deviation (\% RSD) for inter-day and intra-day precision was not more than $2.0 \%$. Hence, the proposed method can be applied accurately for research and routine analysis of linagliptin in bulk as well as different pharmaceutical dosage forms.
\end{abstract}

Key words: Linagliptin, Liquid Chromatography, RP-HPLC, PDA detector, ICH Q2(R1) guidelines, Validation

\section{INTRODUCTION}

Linagliptin is anoral hypoglycemic drug of the new dipeptidyl peptidase-4 (DPP-4) inhibitor class. ${ }^{1}$ Its chemical name is 8 -[(3R)-3-aminopiperidin-1-yl]7-but-2-ynyl-3-methyl-1-[(4-methylquinazolin-2-yl)methyl]-4,5-dihydropurine-2,6-dione (Figure 1). This enzyme inhibiting drug is to be used either alone as an adjunct to diet and exercise or in combination with metformin or a thiazolidinedione to improve glycemic control in adults with type 2 diabetes mellitus. $^{2-6}$ It competitively inhibits an enzyme, dipeptidyl peptidase-4 (DPP-4) that results in an

Correspondence to: Abu Shara Shamsur Rouf Email: 〈rouf321@yahoo.com>

Dhaka Univ. J. Pharm. Sci. 17(2): 175-182, 2018 (December) DOI: http://dx.doi.org/10.3329/dujps.v17i2.39173 increased amount of active incretins, i.e. glucagonlike peptide-1 (GLP-1) and glucose-dependent insulinotropic polypeptide (GIP), which in turn reduce the release of glucagon and increase the release of insulin. ${ }^{7}$<smiles>CC#CCn1c(N2CCCCC2)nc2c1c(=O)n(Cc1nc(C)c3ccccc3n1)c(=O)n2C</smiles>

Figure 1. Structure of linagliptin.

The current work is a continuation of our research activities in the field of food and drug. ${ }^{8-14}$ The current method, we are proposing, is versatile, 
sensitive, rapid, cost effective and validated to determine linagliptin.

Literature review revealed that linagliptin can be determined alone or in combination with UV spectrophotometry ${ }^{15,16}$, UPLC ${ }^{17}$ and RP-HPLC ${ }^{18-22}$ techniques. UV spectrophotometry is a simple method but lack of accuracy and precision. HPLC is the most suitable for analysis because the method is very simple and shows greater sensitivity. However, most of the reported methods were associated with complex mobile phase composition ${ }^{21}$, higher percentage of organic solvent in mobile phase $\mathrm{e}^{18,20,21}$ and relatively higher retention time. ${ }^{18-21}$ To overcome those shortcomings, we aimed to develop an accurate and rapid RP-HPLC method using simple mobile phase composition with relatively lower amount of organic solvent for routine quantitative and qualitative analysis of linagliptin in bulk and pharmaceutical dosages forms.

\section{MATERIALS AND METHODS}

Chemicals and reagents. Standard linagliptin powder was purchased from Zhejiang Wuyi Jiyan Pharm Chem, China whereas linagliptin tablet (Ligatin $5 \mathrm{mg}$ ) was a generous gift from Eskayef Pharmaceuticals Ltd., Bangladesh. HPLC grade acetonitrile was procured from RCI Labscan Ltd. (Thailand). Analytical grade potassium dihydrogen phosphate and hydrogen peroxide (30\%) were procured from BDH Chemicals (England) and Scharlau, Spain respectively. Sodium hydroxide pellets, hydrochloric acid (37\%) and acetone were obtained from Merck, Germany. HPLC grade water was prepared from Millipore Milli-Q water purification system from Evoqua Water Technologies, USA. All other materials and reagents were of analytical grade.

Chromatographic conditions. The analysis of the drug was carried out on an artificial HPLC system (Perkin Elmer) where $20 \mu \mathrm{L}$ of samples were injected into $\mathrm{C}_{18}$ column $(150 \times 4.6 \mathrm{~mm}$ i.d., $5 \mu \mathrm{m}$ particle size) and run time was set at 10 minutes. The elute was detected through a PDA detector at $239 \mathrm{~nm}$ and the retention time was found to be 2.8 minutes. The shorter retention time with better resolution was obtained due to the HPLC system which provided higher pressure during the elution of the analyte. An isocratic method with a flow rate of $1 \mathrm{ml} / \mathrm{min}$ was used to elute the compounds with a mobile phase composed of 70:30 v/v mixture of phosphate buffer $(\mathrm{pH} 6.8 \pm 0.2)$ and acetonitrile. All the data were evaluated by Chromera software.

\section{Preparation of solutions}

Preparation of phosphate buffer solution. Potassium dihydrogen phosphate $(3.4 \mathrm{~g})$ and sodium hydroxide pellets $(0.472 \mathrm{~g})$ were weighed carefully and taken into a $500 \mathrm{ml}$ volumetric flask. About 300 $\mathrm{ml}$ of HPLC grade water was added in the volumetric flask and sonicated until the salts were dissolved. Finally, the volume was adjusted to $500 \mathrm{ml}$ with the help of HPLC grade water.

Preparation of mobile phase (MP). Phosphate buffer $(\mathrm{pH} 6.8 \pm 0.2)$ and acetonitrile were mixed following 70:30 (v/v) ratio and then sonicated for at least 15 minutes. After sonication was done, the resulting mobile phase was filtered in RESTEK vacuum filter using a $0.22 \mu \mathrm{m}$ membrane filter.

Preparation of standard solutions. Accurately weighed quantity $(10.0 \mathrm{mg})$ of standard linagliptin was transferred to a $10.0 \mathrm{ml}$ volumetric flask and dissolved in $5 \mathrm{ml}$ of MP and sonicated for 10 minutes in ultra sonicator. The volume was made up to the mark with MP to get the final concentration of 1 $\mathrm{mg} / \mathrm{ml}$. As per the requirement five solutions (40, 45, 50,55 and $60 \mu \mathrm{g} / \mathrm{ml}$ ) were prepared with proper dilution with the diluting medium.

Preparation of sample solution. Five tablets were taken and their average weight was calculated. Then the tablets were crushed and powdered finely with a mortar pestle. To prepare assay sample solution, powdered sample equivalent to $10 \mathrm{mg}$ of linagliptin was weighed and transferred to a clean and dry $10 \mathrm{ml}$ volumetric flask. About $5 \mathrm{ml}$ of diluting solution [70:30 v/v mixture of phosphate buffer (pH 6.8 \pm 0.2$)$ and acetonitrile] was added and shaken thoroughly to extract the drug from the excipients for 15 minutes and then sonicated for 15 
min for complete dissolution of drug. The solution was brought to room temperature and then the volume was made up to the mark with the same diluting solution. From this solution, $0.5 \mathrm{ml}$ was transferred to a clean and dry $10 \mathrm{ml}$ volumetric flask and the volume was made up to the mark with the same diluent. The solution was then filtered through Whatman filter paper (No. 42) and then finally filtered through $0.2 \mu \mathrm{m}$ disk filter. Thus, we got a sample solution having drug concentration of 50 $\mu \mathrm{g} / \mathrm{ml}$. Then the drug concentration of the resulting sample solution was determined by HPLC using the calibration curve of standard solution. All determinations were conducted in triplicate.

Validation of the proposed method. The proposed method was validated as per current regulatory guidelines. ${ }^{23,24}$

System suitability. To assess system suitability of the proposed method (repeatability, theoretical plates, tailing factor, and retention time of six replicate) vials containing the working standard of linagliptin of nominal concentration $(50 \mu \mathrm{g} / \mathrm{ml})$ were used and percentage relative standard deviation ( $\%$ RSD) values were calculated in each case.

Linearity. The linearity was evaluated by analyzing five working solutions of linagliptin over the concentration range $40-60 \mu \mathrm{g} / \mathrm{ml}$. A calibration curve was prepared and the linearity was evaluated by linear regression analysis, which was then evaluated by the least- square regression analysis. The regression line was calculated as $\mathrm{y}=\mathrm{mx}+\mathrm{c}$; where, $y, m, x$ and $\mathrm{c}$ represent the response (peak area expressed as $\mathrm{mAU}$ ), the slope of the regression line, the concentration of linagliptin in $\mu \mathrm{g} / \mathrm{ml}$ and the intercept of the regression line, respectively.

Specificity. The specificity of the developed method was determined by blank analysis. A blank sample was prepared for this study and was treated in the same manner as the test samples.

Accuracy (recovery test). Accuracy of the proposed method was studied by recovery experiments for both standard and sample solutions. It was assured by the standard addition technique.
The result obtained for both were compared to those expected.

Precision. To determine the repeatability (intraday precision) and intermediate precision (inter-day precision) of the method, both linagliptin standard and sample solutions at nominal standard concentration $(50 \mu \mathrm{g} / \mathrm{ml})$ were analyzed in six replicates on the same day (intra-day precision) and daily for six times over a period of three days (interday precision). The results were expressed as \% RSD of the measurements.

Sensitivity. To perform this, a blank sample (MP) was run in the HPLC system and the pump pressure was monitored. When the pressure fluctuation became negligible, highly diluted standard solutions of linagliptin were run through the same chromatographic condition. The LOD and LOQ were determined based on the standard deviation (SD) of the response and slope (S) of the regression line as per ICH guidelines. Equation i and ii represent the formulas for determining LOD and LOQ, respectively.

$$
\begin{aligned}
\mathbf{L O D} & =\frac{3.3 \times \mathrm{SD}}{\mathrm{s}} \\
\mathbf{L O Q} & =\frac{10 \times \mathrm{SD}}{\mathrm{s}}
\end{aligned}
$$

Ruggedness. Ruggedness of the proposed method was determined by analyzing six assay sample solutions of linagliptin at nominal concentration by two analysts to check the reproducibility of the test results. The percentage recovery and percent relative standard deviation (\% RSD) were calculated in both cases.

Robustness. The robustness is the ability of a method to remain unaffected by small deliberate changes in chromatographic parameters. To determine the robustness of the current method, $\mathrm{pH}$ of the buffer solution, mobile phase compositions and flow rate were changed and \% RSD of those changed conditions were calculated. 


\section{RESULTS AND DISCUSSION}

System suitability. The data (mean $\pm \%$ RSD) of the chromatographic parameters obtained after six replicate injections of the sample at the nominal concentration are shown in table $1 . \%$ RSD values of not more than $2 \%$ indicated the good performance of the proposed method.

Table 1. System suitability parameters.

\begin{tabular}{lcc}
\hline Parameters & Value (Mean $\pm \%$ & Acceptable limit \\
& RSD) & \\
\hline Peak area & $2948092.657 \pm 1.31$ & $\%$ RSD $\leq 2$ \\
Tailing factor & $1.403 \pm 0.16$ & $\leq 1.5$ \\
Theoretical plate & $5703.53 \pm 0.37$ & $\geq 2000$ \\
Retention time & $3.26 \pm 0.23$ & $\%$ RSD $\leq 0.5$ \\
\hline
\end{tabular}

Specificity. The chromatogram recorded for the blank revealed no interfering peaks of linagliptin standard and sample solution within retention time (around 2.8 minutes), which indicated good specificity of the method under experiment (Figure 2).

Linearity. The calibration curve was obtained using the linear least square regression procedure. The representative linear equation obtained was $\mathrm{y}=$ $53234 x+283611$ where, $y$ and $x$ represent the average peak area and concentration of standard linagliptin solution, respectively over the concentration range of (40 - $60 \mu \mathrm{g} / \mathrm{ml})$ (Figure 3).
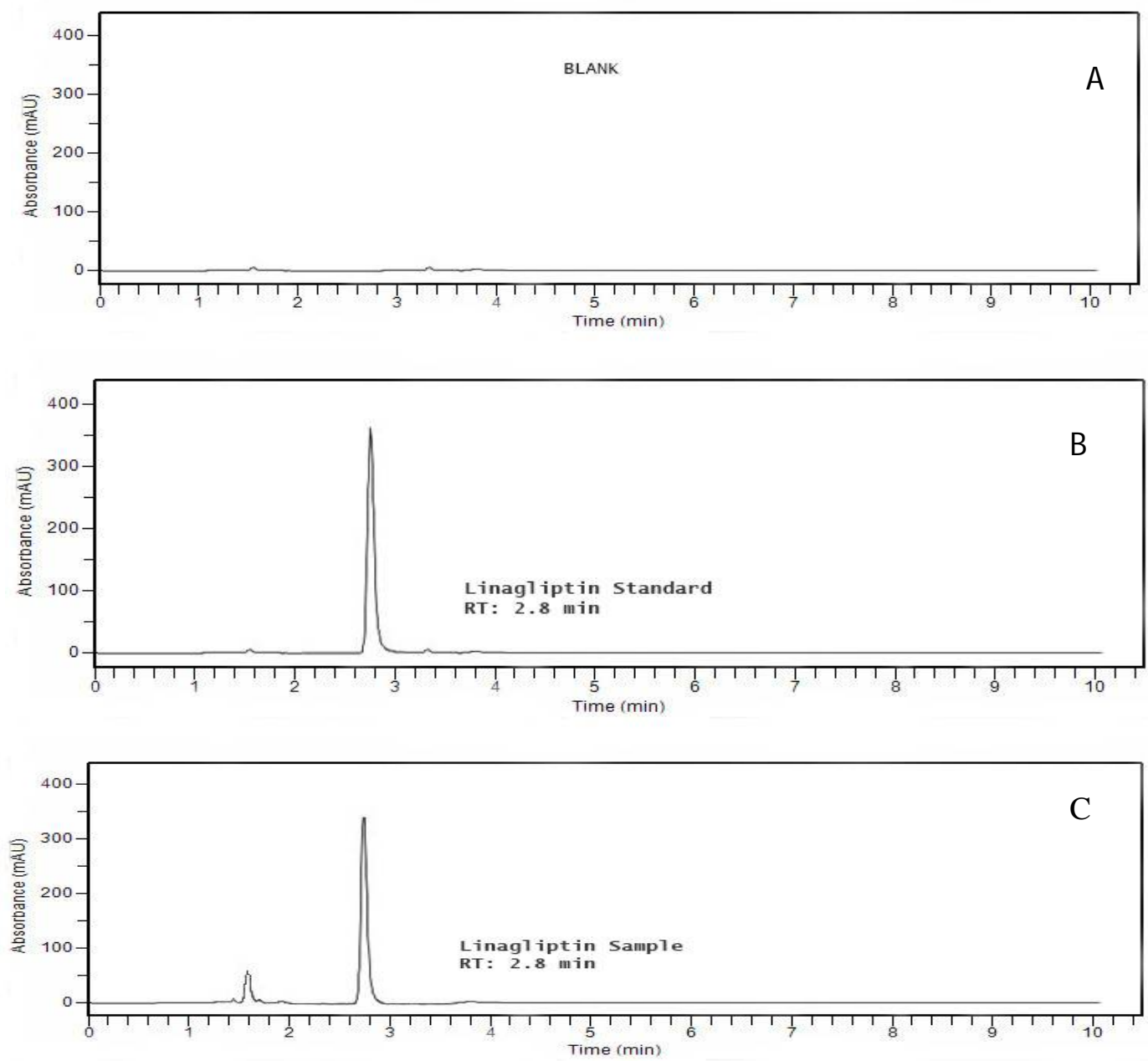

Figure 2. Chromatogram of (A) blank sample, (B) standard solution of linagliptin (50 $\mu \mathrm{g} / \mathrm{ml})$ and (C) sample solution of linagliptin $(50 \mu \mathrm{g} / \mathrm{ml})$ 


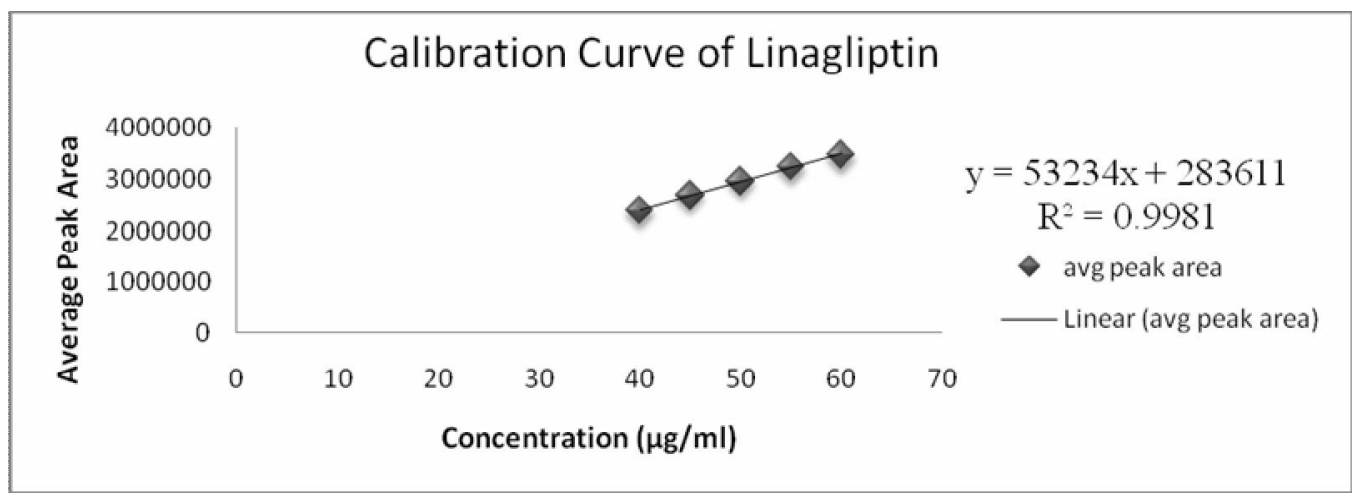

Figure 3. Calibration curve of linagliptin

Accuracy. Accuracy of the method was studied by recovery tests. The overall results of percent recoveries (mean $\pm \%$ RSD of three replicates) of linagliptin in pure working standard and sample solutions are presented in table 3 . The calculated recovery values of linagliptin ranged from $99.12 \% \pm$ 0.03 to $100.47 \% \pm 0.08 \%$ RSD in pure and from $99.48 \% \pm 0.38$ to $100.22 \% \pm 0.011 \%$ RSD in sample solutions which indicated good accuracy of the proposed method.
Precision. The results obtained from repeatability (intra-day) and intermediate day (interday) precision analyses are listed in table 4 as mean of \% recovery. Since the \% RSD values of both standard and sample linagliptin solutions were found to be less than $1 \%$ in all cases, there were no significant differences between assay results either within day or between days.

Table 3. Result of accuracy study of linagliptin in standard and sample solution.

\begin{tabular}{rcc}
\hline Type of Solution & Amount added $(\mu \mathrm{g} / \mathrm{ml})$ & $\%$ Recovery $($ Mean $\pm \%$ RSD $)$ \\
\hline \multirow{3}{*}{ Standard solution } & 40 & $99.967 \pm 0.55$ \\
& 45 & $99.91 \pm 0.29$ \\
& 50 & $100.47 \pm 0.08$ \\
& 55 & $100.36 \pm 0.36$ \\
Sample solution & 60 & $99.12 \pm 0.03$ \\
& 40 & $99.52 \pm 0.16$ \\
& 45 & $99.48 \pm 0.38$ \\
& 50 & $100.08 \pm 0.48$ \\
\end{tabular}

Table 4. Intra-day and inter-day precision data for linagliptin $(n=6)$.

\begin{tabular}{|c|c|c|c|c|c|c|}
\hline \multirow{2}{*}{$\begin{array}{l}\text { Type of } \\
\text { solution }\end{array}$} & \multirow{2}{*}{$\begin{array}{c}\text { Spike level } \\
(\%)\end{array}$} & \multirow{2}{*}{$\begin{array}{c}\text { Intra-day } \\
\% \text { recovery } \\
\text { (Mean } \pm \% \text { RSD) }\end{array}$} & \multicolumn{3}{|c|}{$\begin{array}{l}\text { Inter-day } \% \text { recovery } \\
\quad(\text { Mean } \pm \% \text { RSD })\end{array}$} & \multirow{2}{*}{$\begin{array}{c}\text { Average inter-day } \\
\% \text { recovery } \\
\text { (Mean } \pm \% \text { RSD) }\end{array}$} \\
\hline & & & Day 1 & Day 2 & Day 3 & \\
\hline $\begin{array}{l}\text { Standard } \\
\text { solution }\end{array}$ & $100^{*}$ & $99.55 \pm 0.31$ & $99.75 \pm 0.19$ & $99.82 \pm 0.16$ & $100.21 \pm 0.51$ & $99.92 \pm 0.37$ \\
\hline Sample solution & $100^{*}$ & $100.084 \pm 0.45$ & $99.96 \pm 0.36$ & $100.05 \pm 0.65$ & $100.03 \pm 0.77$ & $100.017 \pm 0.58$ \\
\hline
\end{tabular}

* Spike level $100 \%$ indicates $50 \mu \mathrm{g} / \mathrm{ml}$ of linagliptin was spiked in both standard and sample solution. 

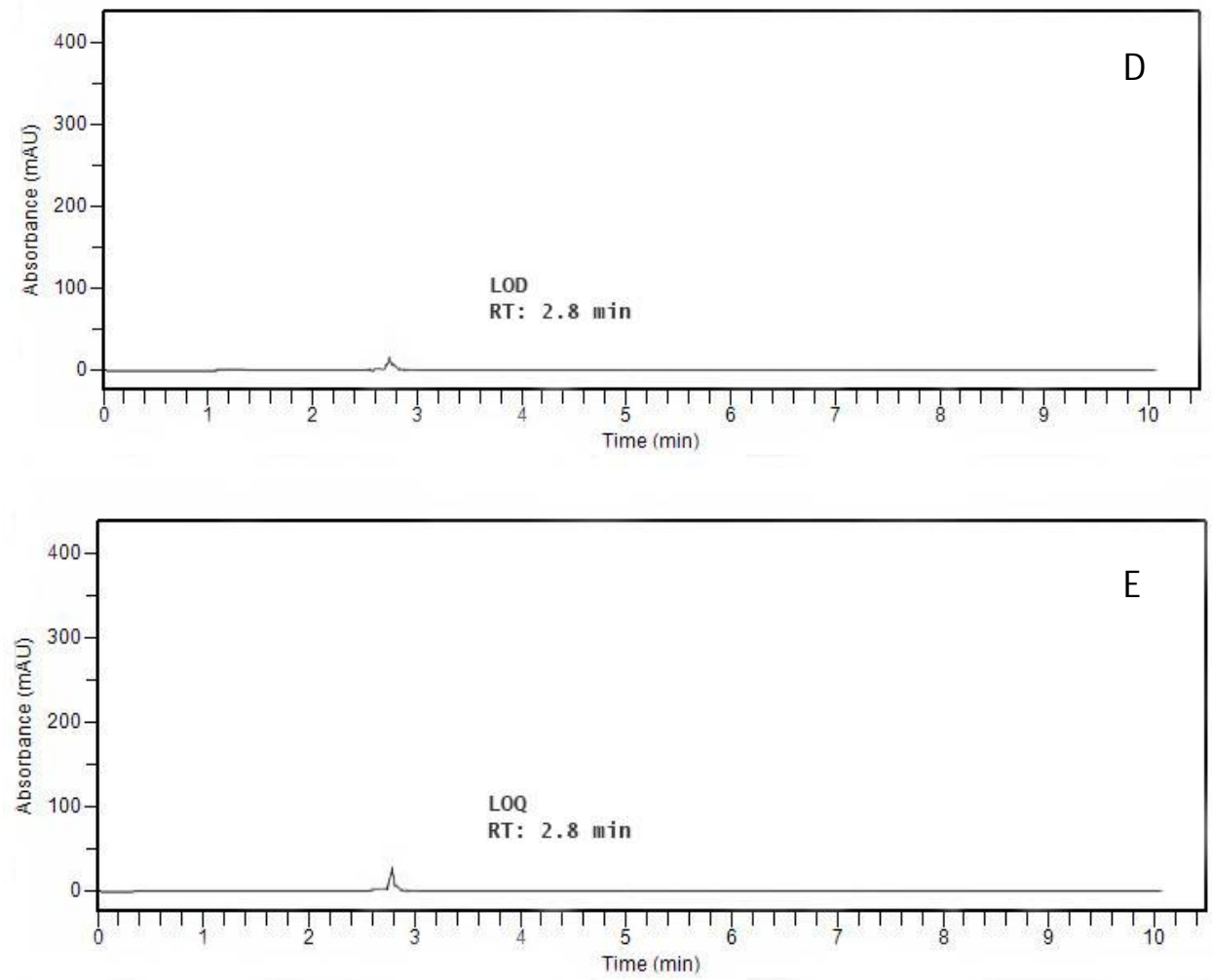

Figure 4. Chromatogram of (D) LOD and (E) LOQ of linagliptin

Sensitivity. After several trials with diluted solution of standard linagliptin, LOD and LOQ values of the proposed method were found to be 0.05 $\mu \mathrm{g} / \mathrm{mland} 0.15 \mu \mathrm{g} / \mathrm{ml}$, respectively. Figure 4 shows the sensitivity of the current method.

Ruggedness. The $\%$ recovery (Mean $\pm \%$ RSD of six assay samples) obtained by analyst 1 and analyst 2 are given in table 5. \% RSD value of not more than $1 \%$ indicated the ruggedness of the current method.

Robustness. The robustness of the experimented method was established by varying the flow rate $( \pm$ $0.1 \mathrm{ml} / \mathrm{min}$ ), mobile phase composition ( $\pm 5 \%$ of acetonitrile) and $\mathrm{pH}$ of the mobile phase $( \pm 0.2)$ and those variations caused a slight deviation in \% recovery but the values of \%RSD were not more than $1 \%$. The observed results are shown in (Table 6).

The proposed method is very fast to elute linagliptin i.e. at about 2.8 minutes whereas elution time of the method developed by Badugu et al. ${ }^{18}$,
Lakshmi et al. ${ }^{19}$, El-Bagary et al. ${ }^{20}$ and Swami et al. ${ }^{21}$ were 5.85 minutes, 7 minutes, 6.6 minutes and 5.4 minutes, respectively. Moreover, our method uses a simple and easy to prepare mobile phase compared to Swami et al. ${ }^{21}$ where phosphate buffer of $\mathrm{pH} 5.6$ (diluted with orthophosphoric acid), methanol and acetonitrile in the ratio of 40:5:55 v/v was used as the mobile phase. Our method also use relatively lower amount of organic solvent i.e. $30 \%$ of acetonitrile in mobile phase composition. whereas, Badugu et al. ${ }^{18}$, El-Bagary et $a .^{20}$ and Swami et $a .^{21}$ used relatively higher amount of organic solvent, that is $83 \%$ of methanol, $80 \%$ of acetonitrile and 5\% of methanol with $55 \%$ of acetonitrile, respectively. Our method showed higher sensitivity with a LOD and LOQ value of $0.05 \mu \mathrm{g} / \mathrm{ml}$ and $0.15 \mu \mathrm{g} / \mathrm{ml}$, respectively. But Zubair et $a l .{ }^{22}$ have not mentioned anything about the sensitivity of their developed method. 
Table 5. Result of ruggedness study $(n=6)$.

\begin{tabular}{lccc}
\hline Type of solution & Amount added $(\mu \mathrm{g} / \mathrm{ml})$ & $\begin{array}{c}\text { Type of } \\
\text { ruggedness }\end{array}$ & $\begin{array}{c}\text { \% Recovery } \\
\text { (Mean } \pm \% \text { RSD })\end{array}$ \\
\hline \multirow{2}{*}{ Sample solution } & \multirow{2}{*}{50} & Analyst 1 & $100.03 \pm 0.40$ \\
& & Analyst 2 & $99.91 \pm 0.45$ \\
\hline
\end{tabular}

Table 6. Result of robustness study $(n=3)$.

\begin{tabular}{lccc}
\hline Parameters & Variables & Amount added $(\mu \mathrm{g} / \mathrm{ml})$ & $\begin{array}{c}\text { \% Recovery } \\
(\text { Mean } \pm \% \text { RSD })\end{array}$ \\
\hline Flow rate & 0.9 & 50 & $99.92 \pm 0.43$ \\
$(\mathrm{ml} / \mathrm{min})$ & 1.0 & 50 & $99.94 \pm 0.46$ \\
& 1.1 & 50 & $99.99 \pm 0.30$ \\
\hline Mobile phase composition & $65: 35$ & 50 & $99.75 \pm 0.10$ \\
(Buffer - ACN) & $70: 30$ & 50 & $99.87 \pm 0.09$ \\
& $75: 25$ & 50 & $99.78 \pm 0.61$ \\
\hline Mobile phase pH & 6.6 & 50 & $99.61 \pm 0.03$ \\
& 6.8 & 50 & $99.62 \pm 0.56$ \\
& 7.0 & 50 & $99.66 \pm 0.08$ \\
\hline
\end{tabular}

\section{CONCLUSION}

According to ICH Q2(R1) guidelines, the newly developed method has proven to be simple, sensitive, rapid and versatile for determination of linagliptin, which completely complies with the aim of our study. Moreover, the method uses a non-cumbersome and simple mobile phase composition with commonly available and inexpensive reagents. Thus, the developed method is suitable for research as well as routine analysis of linagliptinin bulk and in different pharmaceutical dosage forms.

\section{ACKNOWLEDGEMENTS}

The authors are grateful to Higher Education Quality Enhancement Project (HEQEP), AIF, RoundIII, Window-2, CP-3245, Award No. 26, University Grants Commission (UGC), Bangladesh, for supporting the research work.

\section{CONFLICT OF INTEREST}

The authors declare that there is no conflict of interest.

\section{REFERENCES}

1. Taskinen, M.R., Rosenstock, J., Tamminen, I., Kubiak, R., Patel, S., Dugi, K.A. and Woerle, H.J. 2011. Safety and efficacy of linagliptin as add-on therapy to metformin in patients with type 2 diabetes: a randomized, double-blind, placebo-controlled study. Diabetes Obes. Metab. 13, 65-74.

2. Del, P.S., Barnett, A.H., Huisman, H., Neubacher, D., Woerle, H.J. and Dugi, K.A. 2011. Effect of linagliptinmonotherapy on glycaemic control and markers of $\beta$-cell function in patients with inadequately controlled type 2 diabetes: a randomized controlled trial.Diabetes Obes. Metab. 13, 258-267.

3. Kawamori, R., Inagaki, N., Araki, E., Watada, H., Hayashi, N., Horie, Y., Sarashina, A., Gong, Y.,Eynatten, M.V., Woerle, H.J. and Dugi, K.A. 2012. Linagliptin monotherapy provides superior glycaemic control versus placebo or voglibose with comparable safety in Japanese patients with type 2 diabetes: a randomized, placebo and active comparator-controlled, double-blind study. Diabetes Obes. Metab. 14, 348-357.

4. Gomis, R., Owens, D.R., Taskinen, M.R., Del, P.S., Patel, S., Pivovarova, A., Schlosser, A. and Woerle, H.J. 2012. Longterm safety and efficacy of linagliptin as monotherapy or in combination with other oral glucose-lowering agents in 2121 subjects with type 2 diabetes: up to 2 years exposure in 24 week phase III trials followed by a 78-week open-label extension. Int. J. Clin. Pract. 66, 731-740. 
5. Gomis, R., Espadero, R.M., Jones, R., Woerle, H.J. and Dugi, K.A. 2011. Efficacy and safety of initial combination therapy with linagliptin and pioglitazone in patients with inadequately controlled type 2 diabetes: a randomized, double-blind, placebo-controlled study. Diabetes Obes. Metab. 13, 653-661.

6. Taskinen, M.R., Rosenstock, J., Tamminen, I., Kubiak, R., Patel, S., Dugi, K.A. and Woerle, H.J. 2011. Safety and efficacy of linagliptin as add-on therapy to metformin in patients with type 2 diabetes: a randomized, double-blind, placebo-controlled study. Diabetes Obes. Metab. 13, 65-74.

7. Deacon, C.F. 2011. Dipeptidyl peptidase-4 inhibitors in the treatment of type 2 diabetes: a comparative review. Diabetes Obes. Metab. 13, 7-18.

8. Sultana, S., Kumar, U., Hossain, M.S., Lira, D.N. and Rouf, A.S.S. 2017. QbD Approach for the development and validation of RP-UHPLC method for quantitation of vildagliptin. Dhaka Univ. J. Pharm. Sci. 16, 107-117.

9. Sultana, S., Lira, D.N., Hossain, M.S. and Rouf, A.S.S. 2015. Optimized and validated RP-HPLC Method for the determination of esomeprazole magnesium in pharmaceutical formulation. Dhaka Univ. J. Pharm. Sci. 14, 225-232.

10. Sultana, S., Ahammad, T., Islam, M.A. and Rouf, A.S.S. 2013. RP-HPLC Method development and validation for nitazoxanide in powder for suspension dosage form. Int. $J$. Pharm. Sci. Res. 4, 301-305.

11. Alam, M.M., Hossain, M.S., Bhadra, S., Kumar, U. and Rouf, A.S.S. 2017. Development and Validation of RP-HPLC Method for quantitation of clarithromycin in matrix tablet dosage form. Dhaka Univ J Pharm Sci. 16, 69-75.

12. Hossain, M.S., Islam, M.S., Bhadra, S. and Rouf, A.S.S. 2016. Screening of caffeine, preservatives and antioxidants in dairy products available in Bangladesh using an RP-HPLC method. Int. J. Food Contam. 3, 11-21.

13. Islam, M.S., Hossain, M.S., Bhadra, S. and Rouf, A.S.S. 2016. Simultaneous determination of caffeine, preservatives and antioxidants in energy-and soft-drinks commercially available in Bangladesh. Dhaka Univ. J. Pharm. Sci. 15, 97-108.

14. Hossain, M.F., Bhadra, S., Kumar, U. and Rouf, A.S.S. 2013. The ICH guidance in practice: Stress degradation studies on aceclofenac and development of a validated stabilityindicating reversed-phase HPLC assay in tablet dosage form. Der. Pharma. Chem. 5, 131-146.
15. Banik, S., Karmakar, P. and Miah, M.A.H. 2015. Development and validation of a UV-spectrophotometric method for determination of vildagliptin and linagliptin in bulk and pharmaceutical dosage forms. Bangladesh Pharm. J. 18, 163-168.

16. Sangeetha, R.K. and Subashri, T. 2016. Analysis of linagliptin in tablet dosage form by UV spectroscopy method, its derivatives and difference spectra. Euro. J. Pharm. Med. Res. 3, 536-540.

17. Dubey, N., Singh, G.N., Tyagi, A., Bhardwaj, R. and Raghav, C.S. 2014. Development and validation of ultra-performance liquid chromatography (UPLC) method for estimation of a new anti-diabetic drug linagliptin in bulk and its tablet formulation. Ind. J. Chem. 53, 1136-1139.

18. Badugu, L.R. 2012. A Validated RP-HPLC method for the determination of Linagliptin. Am. J. Pharm. Tech. Res. 2, 463-470.

19. Lakshmi, B. and Reddy, T.V. 2012. A novel RP-HPLC Method for the quantification of linagliptin in formulations. J. At. Mol. 12, 155-164.

20. El-Bagary, R.I., Elkady, E.F. and Ayoub, B.M. 2012. Liquid chromatographic determination of linagliptin in bulk, in plasma and in its pharmaceutical preparation. Int. J. Biomed. Sci. 8, 209-214.

21. Swami, A.J. and Baba, K.H. 2013. Analytical method development and method validation for the simultaneous estimation of metformin HCL and linagliptin in bulk and tablet dosage form by RP-HPLC method. Int. J. Pharm. 3, 594-600.

22. Zubair, M., Murali, B. and Rajesh, G. 2014.RP-HPLC method development and validation of linagliptin in bulk drug and pharmaceutical dosage form. Der. Pharm. Sinica. 5,123-130.

23. Hong, D.D. and Shah, M. 2000. Development and Validation of HPLC stability-indicating assays. Drugs Pharm. Sci.107, 329-384.

24. International conference on harmonization. 2005. Validation of Analytical Procedures: Texts and Methodology, Q2 (R1). IFPMA, Geneva, Switzerland. 